\title{
Care management in coping with COVID-19 at a teaching hospital
}

\author{
Gestão do cuidado no enfrentamento da COVID-19 em hospital de ensino \\ Gestión de la atención para enfrentar el COVID-19 en un hospital universitario
}

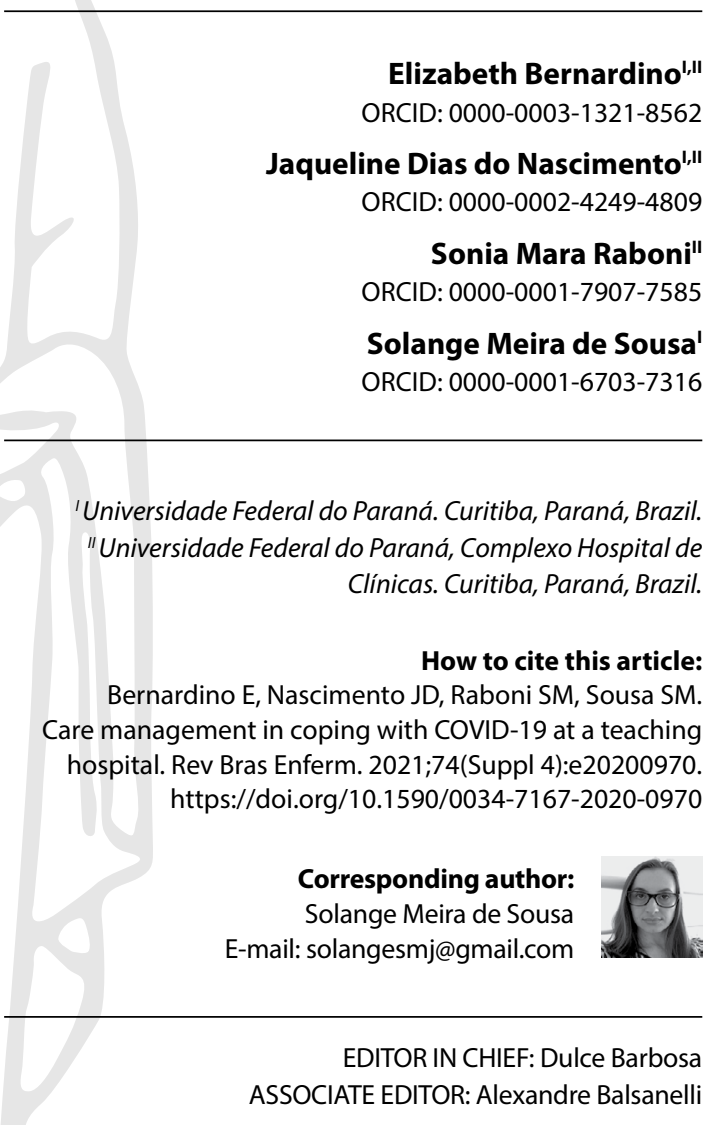

Submission: $08-25-2020$

Approval: $10-30-2020$

\begin{abstract}
Objective: to report the experience of implementing care management strategies in coping with the COVID-19 pandemic in a teaching hospital. Method: this is an experience report of the managers who work at the largest public hospital in Paraná with functions as Head of the Care Management Division, Head of the Care Lines Management Sector, Head of the Infectiology Unit and support team. Results: care management strategies were structured based on the service dynamics; physical structure; human Resources; professional and user safety. Final considerations: preparing for a pandemic involves measures that include modifying infrastructure and processes, managing employees and users, infection prevention strategies, and clinical recommendations. These measures are necessary to optimize the quality of care provided to users with COVID-19 and to reduce the risk of viral transmission to other users or health professionals.
\end{abstract}

Descriptors: Betacoronavirus; Coronavirus infections; Health Assistance; Health Services Administration; Health Management.

\section{RESUMO}

Objetivo: relatar a experiência de implementação de estratégias de gestão do cuidado no enfrentamento à pandemia de COVID-19 em hospital de ensino Método: trata-se de relato de experiência dos gestores que atuam no maior hospital público do Paraná, tendo como funções a Chefia de Divisão de Gestão do Cuidado, Chefia de Setor de Gestão das Linhas de Cuidado, Chefia da Unidade de Infectologia e equipe de apoio. Resultados: as estratégias de gestão do cuidado foram estruturadas a partir da dinâmica de atendimento, estrutura física, recursos humanos, segurança do profissional e do usuário. Considerações finais: a preparação para uma pandemia envolve medidas que incluem modificação de infraestrutura e processos, gerenciamento de funcionários e usuários, estratégias de prevenção de infecções e recomendações clínicas. Essas medidas são necessárias para otimizar a qualidade dos cuidados prestados aos usuários com COVID-19 e reduzir o risco de transmissão viral a outros usuários ou profissionais de saúde.

Descritores: Betacoronavirus; Infecções por Coronavirus; Assistência à Saúde; Administração de Serviços de Saúde; Gestão em Saúde.

\section{RESUMEN}

Objetivo: reportar la experiencia de implementar estrategias de gestión de la atención en el afrontamiento de la pandemia de COVID-19 en un hospital docente Método: este es un reporte de experiencia de los gerentes que laboran en el hospital público más grande de Paraná, con el Jefe de División de Gestión Asistencial, Jefe del Sector Gestión de las Líneas de Atención, Jefe de la Unidad de Enfermedades Infecciosas y equipo de apoyo. Resultados: las estrategias de gestión del cuidado se estructuraron con base en la dinámica del cuidado, la estructura física, los recursos humanos, la seguridad del profesional y del usuario. Consideraciones finales: la preparación para una pandemia implica medidas que incluyen la modificación de la infraestructura y los procesos, la gestión de empleados y usuarios, estrategias de prevención de infecciones y recomendaciones clínicas. Estas medidas son necesarias para optimizar la calidad de la atención brindada a los usuarios con COVID-19 y para reducir el riesgo de transmisión viral a otros usuarios o profesionales de la salud.

Descriptores: Betacoronavirus; Infecciones por Coronavirus; Prestación de Atención de Salud; Administración de los Servicios de Salud; Gestión en Salud. 


\section{INTRODUCTION}

Acute viral respiratory infections are the main causes of morbidity and mortality worldwide. The detection and dissemination of any respiratory pathogen are accompanied by uncertainties about its epidemiological, clinical and virological characteristics and, in particular, about the severity of the cases determined by the capacity of dissemination in the population and its virulence. These aspects are no different in the disease caused by the new SARS-CoV-2 coronavirus, called COVID-19, first detected in the city of Wuhan (China) in December 2019. It is a respiratory tract infection caused by an emerging virus whose genetic sequencing indicates that it is a beta-coronavirus, with a high similarity $(79 \%)$ with SARS-CoV(1).

After the initial reports of this disease, the numbers of infected people increased exponentially with the spread of the virus across all continents. On March 11, 2020, COVID-19 was characterized by the World Health Organization (WHO) as a pandemic ${ }^{(2)}$.

The development of vaccines and therapies for COVID-19 is underway; however, there are still no effective therapeutic and preventive measures, and non-pharmacological interventions are recommended for its control, which include isolating patients and social distancing. The wide spread of the disease has generated a high demand for hospital care in a short period of time, overburdening health services and causing even the most robust health systems to collapse. Thus, there was an intensification of pressure on the global health workforce, overburdening the health system and causing adverse effects on health professionals, including the risk of infection ${ }^{(3)}$.

COVID-19 has had a significant impact on the world economy and the organization of all health systems. In the hospital context, in situations of emerging diseases of pandemic potential there is a need for strategies to manage space, staff and supplies, in order to provide the best care to users. Moreover, implementing preventive measures for hospital transmission is a priority ${ }^{(4)}$. However, this pandemic is unprecedented, worldwide government leaders and health managers are adopting emergency measures to deal with this health crisis, adjusting decision-making in real time and seeking to repair the errors that are occurring due to the scarce time to planning ${ }^{(5)}$.

Worldwide, up to the first half of August, more than 21,480,111 cases of the disease and more than 771,518 deaths were recorded. These numbers continue to increase daily, with 107,232 deaths in $\mathrm{Brazi}^{(6)}$. In this sense, an adequate care management understood in a systematic perspective as the set of health services, with its different functions and different degrees of technological incorporation and the flows that are established between them, is necessary. Such flows are defined by protocols controlled by job vacancy or appointment centers, always with the perspective of guaranteeing users' access to the care technologies they need through the constitution and management of complex institutional "care networks". They are operated through formal referral and counter-referral processes, which allow the circulation of people through an articulated set of health services of different and complementary complexities ${ }^{(7)}$.

In this time of pandemic, teaching hospitals were requested by managers to offer ICU beds and specialized wards. They had to quickly perform care management and reconfigure their structure to meet a user profile with an unknown disease, hire and train professionals, update their service letter, cancel elective procedures, direct financial and human resources, adapt physical structure and work processes.

Considering this demand, a search was made for existing literature on the experience of other hospitals and on the expertise of managers to reorganize care management in coping with COVID-19 at a teaching hospital in southern Brazil.

\section{OBJECTIVE}

To report the experience of implementing care management strategies in coping with the COVID-19 pandemic at a teaching hospital.

\section{METHODS}

This is an experience report of health managers working at the largest public hospital in Paraná, with functions as Head of the Care Management Division, Head of the Care Lines Management Sector, Head of the Infectiology Unit and support team.

To elaborate care management strategies for coping with the COVID-19 pandemic, national and international recommendations for coping with COVID 19 were used, such as WHO regulations, Ministry of Health, Brazilian Sanitary Surveillance Agency (Agência Nacional de Vigilância Sanitária), Health Department of Paraná State and Health Department of the Municipality of Curitiba and past management expertise.

Regulatory flows and agreement with the Health Care Network (financing, contracts, qualification) were also considered, as well as scientific evidence in the establishment of internal protocols for structuring the crisis committee, flow design, strategies for clinical management, staff training.

The teaching hospital reported here has the function of training human resources in health, tertiary level assistance and research in the health field. It assists the population of Curitiba, the Metropolitan Region and other states through contracting services and qualitative goals, with $100 \%$ service through SUS. It is member of Universidade Federal do Paraná, and, since October 2014, joined the network of the Brazilian Company of Hospital Services (EBSERH - Empresa Brasileira de Serviços Hospitalares) through shared management.

The hospital has 650 beds in the national health establishment registry, 435 of which are active in tertiary care for the most diverse medical specialties. The beginning of the care management strategies for coping with COVID-19 occurred in mid-February 2020, and the restructuring plan was initiated on March 24, 2020. A crisis office was created with infectious disease, epidemiologist, medical division supplies, care management, diagnostic support and high governance. Currently, the hospital has contracted 76 intensive care beds and 103 nursing beds for the care line for people with COVID-19, whose entrance door is regulated by the regulatory complex of the Municipal Health Department.

\section{RESULTS}

Care management strategies were structured based on service dynamics, physical structure, human resources, professional safety and user safety. 


\section{Service dynamics}

First, with the increase in confirmed cases in the country, the aim was to reduce the number of people circulating in the institution, considering that, prior to the pandemic, approximately 8,000 people/day accessed the hospital's facilities. In this regard, non-essential recreational, educational, teaching activities, among others, were suspended. The suspension of visits and minimum maintenance of companions provided for by law was regulated.

Screening tents were installed at the hospital's entrance doors, with monitoring for the presence of respiratory signs and symptoms indicative of suspected cases of COVID-19 in all persons who sought the hospital. In this location, due to the suspicion of this infection and the presence of signs of seriousness, users are referred to a Referenced Unit (emergency entry unit). If the cases are considered as mild, they are referred to home isolation with return guidance if there are signs of clinical worsening.

In order to prioritize care, considering that the hospital is a reference for referral of users with difficult to manage chronic clinical conditions, with a predominantly elderly clientele, it was necessary to stratify the procedures into elective, essential elective, and emergencies.

Thus, due to the short space of time and the finitude of resources, it was necessary to reduce $79 \%$ of elective consultations (from approximately 35,000 consultations per month to 7,350 consultations per month), and there was still an indefinite block of exams and elective surgical procedures. To this end, medical specialties screened the agendas and medical records seeking to identify the types of care that should remain and prioritizing the maintenance of care to oncological, hematological care lines, transplants, chest pain, stroke, habitual risk pregnancy and high risk.

Elective surgeries and essential diagnostic and therapeutic support services (those that, even if elective, when not performed in a period of 3 months, can cause sequelae and become urgent or even emergency surgeries) were scheduled with a longer surgical time to accommodate additional infection prevention measures, such as testing for COVID-19 prior to admission.

Having defined the new service charter and scaling up the service capacity for the public health emergency period, it was necessary to block 92 beds between clinical and surgical wards and ICUs. This blocking of beds and the supply of available human resources, supplies and equipment led to the reclassification and opening of new beds, whose contract with the local manager reached 179 beds ( 76 in ICU and 103 in ward), 2 screening tents and a referenced unit (Regulated Emergency Service), exclusively for users with respiratory symptoms.

The line of care includes initial screening, care in referenced units, wards and ICUs. Discharge is counter-referred by the discharge management service for follow-up at the outpatient clinic for post-COVID-19 care.

\section{Physical structure}

To make the proposed number of beds available, changes were made to the institution's physical structure. The objective was to optimize and readjust the existing physical structure to assist users with COVID-19, with an emphasis on professional and user safety. It was necessary to review the availability of medicinal gauze; adequacy of the electrical network; acquisition of new generators to support the high number of equipment, mainly related to the increase in ICU beds; inclusion of glass displays on the doors of the wards to reduce the frequency of the multidisciplinary team entering the room; closing and signaling of crossing places for COVID-19 users with indication on the ground and physical blocks restricting the circulation of people as much as possible; elevator reservation exclusively for employees and users with COVID-19; adequacy and addition of sinks for hand washing, adjustment of rooms for dressing, cafeteria, staff accommodation; review and adjustment of ventilation systems; signage with signs and signs for the new environments, distinguishing between clean, potentially contaminated and contaminated areas, among others.

\section{Human resources}

With regard to human resources, the objective was to safely relocate the number of existing professionals, in addition to planning the workforce quantitatively and qualitatively and training the different groups for the new necessary activities. To this end, a mapping of professionals with interest and competence to perform in the care areas specifically designed for COVID-19 (screening, ICU, wards) was carried out. Still, with the occupational health service, risk group employees were stratified, as provided for in Normative Instruction 19 of March 12, 2020. This Normative establishes guidelines for the bodies and entities of the Civil Personnel System of the Federal Public Administration (SIPEC - Sistema de Pessoal Civil da Administração Pública Federal) regarding protection measures to deal with the public health emergency of international importance resulting from COVID-19. Servers that were not released for remote work were allocated according to their skills for tele-orienting servers, users and family members. Due to absenteeism of the order of approximately 20 to $30 \%$ of the workforce, 300 temporary employees were hired for the areas related to serving COVID-19.

The training for professionals in the permanent and temporary staff was on: the new organizational structure for coping with COVID-19; adequate attire, based on NR32, which establishes measures to protect the safety and health of workers with the preparation of institutional videos; preparation of clinical user management protocols with COVID-19 in intermediate and intensive care (suspected, confirmed and discarded); technical guidelines that included the collection of respiratory samples, referral and counter-referral internal flows, access and awareness of institutional protocols; encouraging initiative, flexibility for innovation and change in the work process; awareness of professionals to work in a stressful environment; encouragement of teamwork and empathy among co-workers, among others.

In order to improve the communication channel with more than 4,000 permanent professionals and 1,000 outsourced workers, the communication unit released a daily epidemiological bulletin; e-mail updates to all employees and electronic newsletter publications on the intranet; reports and warnings on computer screensavers; elaboration of institutional videos on social networks and internal panels with photos of the teams motivating the groups and recognizing the work spent; news and notes on social media and press. The role of the ombudsman to communicate concerns and suggestions for high governance was also widely disseminated. 


\section{User and professional safety}

The main strategic actions to minimize the risk of contamination of professionals and users were: establishment of adequate screening and cohort (use of protocols and epidemiological criteria to allocate users to beds compatible with their clinical condition); stratification of access (clean, contaminated and potentially contaminated area) - with physical barrier; team division for direct care and support care; vigilance towards them and co-workers in activities with potential contamination; differentiation of teams into teams - intubation, quick response; discharge management with case monitoring and reinforcement of bed regulation. For Emergency and Diagnostic Support Services, professionals were trained in safe protocols and assistance flows.

Guidance was provided for the case of travel to endemic areas, with a 14-day leave for professionals who traveled to these areas; monitoring and directing symptomatic professionals; active surveillance by the Occupational Health and Safety at Work Service (SOST - Serviço de Saúde Ocupacional e Segurança do Trabalho); identification of professionals who work in other health institutions to assist users with COVID-19; establishment of a psychological support team with psychology and psychiatry service for employees; provision of meals and snacks in the units to avoid travel and agglomerations; adjustments in the percentage of payment for acting in an unhealthy environment; provision of an internal resting environment in the hospital area to preserve the distance; separation of teams according to the degree of exposure.

With regard to professionals, symptomatic patients were attended to and mass testing of professionals (more than 5,000 professionals were tested) with removal of those with active disease. A strategy was instituted to adapt the care work process (nursing, doctor, physiotherapy) aiming at reducing the time spent in contact with a contaminated environment. Periods were established for debriefing and decompression, study of potential/possible forms of contamination and, finally, beginning of the voluntary influenza vaccination protocol.

Regarding user safety, a line of care was established for COVID-19 users from entry to post-discharge in specific outpatient clinics managed by discharge management service. Promotion of knowledge related to the disease was also carried out through truthful information, active listening and empathy with users and family members and encouragement of assertiveness use in the relationships between professionals and users; awareness of the effects of isolation, involving professionals such as occupational therapists, pedagogues, psychologists, use of TVs and watches in the wards and a device for communication between user and family (virtual visit), encouraging users about optimistic attitudes to cope with disease, collection of donations for the composition of a personal care kit due to absence of family visits (oral hygiene, slippers and slippers, bathrobes) and formation of a family information team (team of professionals designated to maintain the link between the information offered by the assistance team and doubts and guidelines assigned to families).

\section{DISCUSSION}

The SARS-CoV-2 pandemic was characterized by an unprecedented challenge for the world population and for public health, even in high-income countries. The challenges are due to lack of knowledge about the disease and all its implications, such as lack of therapeutic supplies and personal protective equipment, a shortage of emergency hospital beds and an exhausting workload for health professionals. These face a high rate of contamination, seeming to tend to develop symptoms more severe than most of the population, probably due to exposure to higher viral loads present in users with severe disease who are hospitalized and therefore need their working conditions to be guaranteed ${ }^{(8)}$.

Virus respiratory transmission due to exposure to droplets, aerosols and contact with an infected individual leads to the need to implement air and contact precautions, in addition to intensifying environmental hygiene and general infection prevention practices ${ }^{(9-10)}$. Moreover, the risk of aerosol transmission during some specific airway handling procedures has drawn attention to increasingly stringent care in user assistance procedures. Thus, prevention and control measures must be practiced in user care in all stages covered by them from admission, screening, waiting, assistance, procedures performed, until their discharge/transfer or death ${ }^{(10)}$. Tais medidas envolvem, assim, toda a equipe assistencial e administrativa do hospital.

Professional actions were planned with a focus on user safety and infection prevention, which included reducing aerosol-generating procedures (i.e., airway handling, face mask ventilation, open airway aspiration, user cough) in as far as possible ${ }^{(4)}$, including personal protective equipment such as an apron, gloves and an N95 respirator, plus a face shield/goggles or a motorized respirator and air purifier (PAPR) ${ }^{(9)}$.

Although health professionals recognize that occupational risk is part of the chosen profession, it is necessary to develop psychological support systems for those who, naturally, fear the risk of transmitting the disease to their families, especially those who live with individuals high risk, such as elderly people, immunocompromised or with other chronic medical conditions $s^{(3)}$.

In this regard, training, stratification of professionals who formed a risk group for COVID-19 and psychological monitoring for frontline professionals were used as strategies for care management in order to help reduce anxiety. Dissemination of guidelines aimed at reducing intra-household transmissibility ${ }^{(3)}$, which include information on decontamination of the home's surface, including effective products and techniques, were also a strategy to reduce anxiety.

All professionals working at the hospital, including caregivers, support staff, administration and preparation teams, must be trained and oriented as to the need for prolonged action, until they can control this pandemic, with the leadership having the role of emphasizing the importance of self-care as the center of the response. Transparent and thoughtful communication can contribute to trust and a sense of control. Workers need to rest properly and be attended to their critical personal needs and emotional support, thus contributing to maintaining individual and team performance in the long term ${ }^{(3)}$.

In addition to the strategies used to tackle the COVID-19 pandemic, health managers are expected to face two major additional "collateral" problems soon. The first will be the physical and mental exhaustion of the health workforce, along with the worn-out hospital infrastructure. The second will be the growing "delay" of health procedures, resulting from the suspension of the performance of elective procedures for users with chronic diseases. Moreover, containment (and progressive containment) 
measures, aggravated by the economic recession, will undoubtedly affect the mental health (e.g., anxiety, depression) and physical health (e.g., weight gain, unbalanced nutrition) of the population, which will depend more on a deeply saturated health system ${ }^{(5)}$.

\section{Study limitations}

This study is limited to a local reality that is constantly changing in the face of an unprecedented pandemic. Thus, the reality presented here, even based on protocols and scientific evidence, is part of the management experiences of the authors and of the realities that appear in everyday life.

\section{Contributions to nursing}

The study contributes to nursing practice when it brings an experience and a historical record of a large institution, which can be used as a basis for decision-making by health managers.

\section{FINAL CONSIDERATIONS}

Preparing for a pandemic involves considering the different levels in the hierarchy of controls, as well as the different phases of the pandemic. These measures include the modification of infrastructure and processes, management of employees and users, infection prevention strategies and clinical recommendations. It can be a challenge to align the interests and concerns of all parties. However, we believe that these containment measures are necessary to optimize the quality of care provided to users with COVID-19 and to reduce the risk of viral transmission to other users or health professionals.

\section{ACKNOWLEDGMENT}

We thank all professionals who are at the forefront in combating the pandemic and we express our solidarity with all those who lost theirs through COVID-19.

\section{REFERENCES}

1. Team NCPERE. Vital surveillances: the epidemiological characteristics of an outbreak of 2019 novel coronavirus diseases (COVID-19) - China. China CDC Weekly. 2020;2(8):113-22. http://weekly.chinacdc.cn/fileCCDCW/journal/article/ccdcw/2020/8/PDF/COVID-19.pdf

2. Organização Pan-Americana da Saúde (OPAS). Folha informativa - COVID-19 (doença causada pelo novo coronavírus) [Internet]. 2020 [cited 2020 Apr 05]. Available from: https://www.paho.org/bra/index.php?option=com_content\&view=article\&id=6101:covid19\&ltemid=875.

3. Adams JG, Walls RM. Supporting the Health Care Workforce During the COVID-19 Global Epidemic. JAMA. 2020:12. https://doi.org/10.1001/ jama.2020.3972

4. Wong J, Goh QY, Tan, Z, Lie SA, Tay YC, Ng SY, et al. Preparing for a COVID-19 pandemic: a review of operating room outbreak response measures in a large tertiary hospital in Singapore. Can J Anesth. 2020;67:732-45. https://doi.org/ 10.1007/s12630-020-01620-9

5. Deloitte Touche Tohmatsu Limited. What will be the impact of the Covid-19 pandemic on healthcare systems? [Internet] 2020[cited 2020 Aug 15]. Available from: https://www2.deloitte.com/fr/fr/pages/covid-insights/articles/impact-covid19-healthcare-systems.html

6. Ministério da Saúde (BR). Coronavírus Brasil: painel interativo [Internet]. 2020 [cited 2020 Aug 15]. Available from: https://covid.saude.gov.br/

7. Cecilio LCO. A morte de Ivan Ilitch, de Leon Tolstói: elementos para se pensar as múltiplas dimensões da gestão do cuidado. Interface (Botucatu). 2009;13(Suppl. 1):545-55. https://doi.org/10.1590/S1414-32832009000500007

8. Silva FV. Enfermagem no combate à pandemia da COVID-19. Rev Bras Enferm. 2020;73(Suppl 2):e2020sup2. https://doi. org/10.1590/0034-7167-202073suppl201

9. Centers for Disease Control and Prevention. Interim infection prevention and control recommendations for patients with confirmed coronavirus disease 2019 (COVID-19) or persons under investigation for COVID-19 in healthcare settings [Internet]. 2019 [cited 2020 Aug 15]. Available from: https://www.cdc.gov/coronavirus/2019-ncov/infection-control/control-recommendations.html

10. Agência Nacional de Vigilância Sanitária. Nota Técnica nº 04/2020. Orientações para serviços de saúde: medidas de prevenção e controle que devem ser adotadas durante a assistência aos casos suspeitos ou confirmados de infecção pelo novo coronavírus (SARS-CoV-2) [Internet]. 2020 [cited 2020 Aug 02]. Available from: http://portal.anvisa.gov.br/documents/33852/271858/ Nota+T\%C3\%A9cnica+n+04-2020+GVIMS-GGTES-ANVISA/ab598660-3de4-4f14-8e6f-b9341c196b28 